\title{
BUNUH DIRI DALAM AL-QUR'AN
}

\section{(Kajian Tahlîlî QS. Al-Nisâ'/4: 29-30)}

\author{
Oleh: Imam Zarkasyi Mubhar ${ }^{1}$ \\ ${ }^{1}$ Institut Agama Islam Muhammadiyah Sinjai, \\ Jl. Sultan Hasanuddin, No. 20 Balangnipa, Sinjai \\ E-Mail: el.imam086@gmal.com,Tlp.: +6285255540499 \\ $* * *$
}

\begin{abstract}
Abstrak
Penelitian ini adalah penelitian kajian pustaka (library research) yang bertujuan untuk mendeskripsikan mengenai bunuh diri dalam pandangan alQur'an melalui pendekatan tafsir tahlîlî terhadap QS al-Nisâ'/4; 29-30 pada khususnya, dan ayat-ayat yang lain pada umumnya yang berhubungan dengan bunuh diri. Penulis menggunakan pendekatan tafsir. Pengumpulan data dilakukan dengan cara mengutip, menyadur dan menganalisis literaturliteratur yang representatif dan relevan dengan masalah yang dibahas, kemudian mengulas dan menyimpulkannya. Penelitian ini menunjukkan bahwa tindakan bunuh diri menjadi pilihan akhir seseorang apabila tidak menemukan solusi dari problem hidup yang dihadapinya. Al-Qur'an secara tegas melarang tindakan bunuh diri. Dampak buruk bagi pelaku bunuh diri ada tiga, pertama, kesulitan dan kesengsaraan ketika hidup. Kedua, rasa sakit yang luar biasa ketika sakarât al-mawt. Ketiga, ganjaran berupa kekekalan dan siksaan yang tiada henti di neraka. Bunuh diri dapat dicegah dengan cara memelihara kesehatan mental berdasarkan tiga metode, yaitu pertama, metode Imâniyah, yaitu keyakinan bahwa Allah swt. senantiasa memberi petunjuk. Kedua, metode Islâmiyah, yaitu membentuk pribadi seseorang menjadi pribadi yang lebih baik. Ketiga, metode Ihsâniyah, yaitu senantiasa menjaga fikiran dan prasangka baik dalam diri.
\end{abstract}

Kata Kunci: Bunuh Diri dan QS. al-Nisâ'/4: 29-30

\section{PENDAHULUAN}

l-Qur'an merupakan kitab suci yang diturunkan Allah swt. sebagai
pedoman bagi umat manusia agar tetap berada di jalan-Nya yang lurus
dalam menghadapi berbagai riak dan gelombang kehidupan di dunia ini. Al-Qur'ân al-karîm merupakan petunjuk (hudan) bagi manusia dan pembeda (al- 
furqân), hal ini sebagaimana QS. al-Baqarah/2: 185, mana yang benar dan yang salah, mana yang bersih dan mana yang kotor. Ia mengumpulkan hukum-hukum dari ummat-ummat terdahulu serta berita-berita tentang mereka. Di dalamnya terdapat aspek hukum, kisah-kisah umat terdahulu, kabar gembira, peringatan, hari kemudian, dan berbagai aspek lainnya.

Al-Qur'an diturunkan sebagai dasar pedoman manusia untuk mengajak kepada ajaran tauhid, mengajarkan nilai-nilai dan sistem baru tentang ideologi maupun kehidupan dan menuntun mereka kepada perilaku positif dan benar menuju pencapaian kesempurnaan insan yang akan merealisasikan kebahagiaan hidup di dunia dan di akhirat. Hal ini sesuai dengan firman Allah swt. dalam QS al-Isrâ'/17: 9 yang berbunyi:

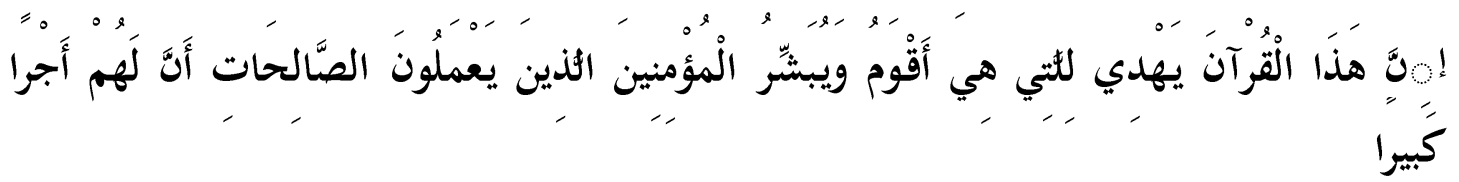

Terjemahnya:

'Sesungguhnya Al-Qur'an ini memberikan petunjuk kepada (jalan) yang lebih lurus dan memberi kabar gembira kepada orang-orang mu'min yang mengerjakan amal saleh bahwa bagi mereka ada pahala yang besar" (Kemenag RI, 2011: 283).

Salah satu hal yang dijelaskan dalam al-Qur'an adalah masalah kehidupan dan kematian. Al-Qur'ân menegaskan bahwa Allah swt. adalah Tuhan yang menganugerahkan hidup dan menentukan mati, sebagaimana disebutkan dalam QS Al-Nahl/16: 70 yang berbunyi:

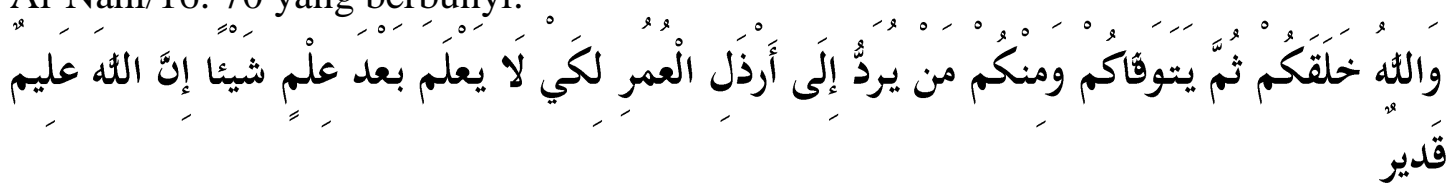

Terjemahnya:

"Allah menciptakan kamu, kemudian mewafatkan kamu, dan diantara kamu ada yang dikembalikan kepada umur yang paling lemah (pikun) supaya dia tidak mengetahui lagi sesuatupun yang pernah diketahuinya. Sesungguhnya Allah maha mengetahui lagi maha kuasa" (Kemenag RI, 2011: 274).

Nilai manusia dalam Islam sangatlah tinggi, bahkan masalah kemanusiaan adalah topik utama yang dibahas dalam al-Qur'ân. Telah diajarkan dalam kitab-Nya 
bahwa "menghilangkan satu saja nyawa manusia (apapun keyakinannya) tanpa alasan yang jelas, seolah-olah telah membinasakan seluruh manusia.

Sebaliknya menghidupi satu saja jiwa manusia seolah-olah ia telah menjaga kehidupan seluruh manusia (QS. al-Mâ'idah/5: 32). Maka apapun alasannya perilaku merusak diri sendiri, membunuh diri dan orang lain tidak ada pembenarannya dalam syariat Islam sebagaimana firman Allah dalam QS al-Nisâ'/4: 29-30 yang berbunyi:

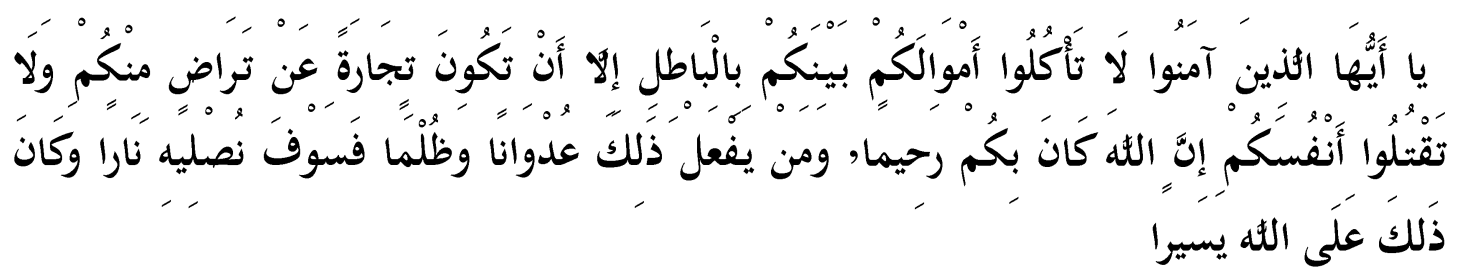

Terjemahnya:

"Hai orang-orang yang beriman, janganlah kamu saling memakan harta sesamamu dengan jalan yang batil, kecuali dengan jalan perniagaan yang Berlaku dengan suka sama-suka di antara kamu. dan janganlah kamu membunuh dirimu. Sesungguhnya Allah adalah Maha Penyayang kepadamu. Dan barangsiapa berbuat demikian dengan melanggar hak dan aniaya, maka Kami kelak akan memasukkannya ke dalam neraka. yang demikian itu adalah mudah bagi Allah" (Kemenag RI, 2011: 83).

Hal tersebut sangat bertolak belakang dengan apa yang sekarang ini terjadi. Akhir-akhir ini banyak terdengar berita tentang maraknya kejadian bunuh diri, baik di dalam negeri maupun di luar negeri, baik dengan menggunakan bahan peledak, dengan melompat dari gedung yang tinggi maupun dengan menggunakan benda atau cara lainnya. Bunuh diri dengan cara meminum racun, gantung diri, terjun bebas, melukai diri, atau dengan bom dan seterusnya adalah sama saja.

Bunuh diri atau dalam bahasa Inggris disebut Suicide (John M. Echols dan Hassan Shadily, 2003: 567) adalah sebuah tindakan sengaja yang menyebabkan kematian diri sendiri. Bunuh diri seringkali dilakukan akibat putus asa, yang penyebabnya seringkali dikaitkan dengan gangguan jiwa misalnya depresi, stres yang disebabkan kesulitan keuangan, gangguan bipolar, ketergantungan alkohol/alkoholisme, atau penyalahgunaan obat serta masalah dalam hubungan interpersonal juga seringkali ikut berperan.

Penjelasan di atas mengindikasikan bahwasanya manusia telah melenceng dari 
apa yang diajarkan al-Qur'an. Mereka tidak lagi menjadikan al-Qur'an sebagai pegangan hidup dan rujukan dalam setiap masalah yang dihadapi, padahal al-Qur'an adalah petunjuk bagi semua manusia.

\section{PEMBAHASAN}

\section{A. Hukum Bunuh Diri Menurut QS. Al-Nisâ'/4: 29-30}

Nyawa manusia, bahkan seluruh jiwa raganya, adalah milik Allah yang diamanatkan kepada masing-masing manusia. Oleh karena itu, manusia tidak dapat menjual nyawa tersebut, karena bukan miliknya. Nyawa pun tidak boleh dipisahkan dari badan kecuali atas izin Allah, misalnya dalam peperangan membela kebenaran atau pelaksanaan sanksi hukum. Atas dasar ini, maka membunuh diri pun dilarang keras oleh Allah swt (M. Quraish Shihab, 2009: 782).

Ibnu al-Munzhir al-Naysâbûrî dalam tafsirnya mengutip sebuah hadis Nabi saw. Yang berbunyi (Abû Bakr Muhammad bin Ibrâhim bin al-Munzhir al-Naisabûrî, 2002: 661).

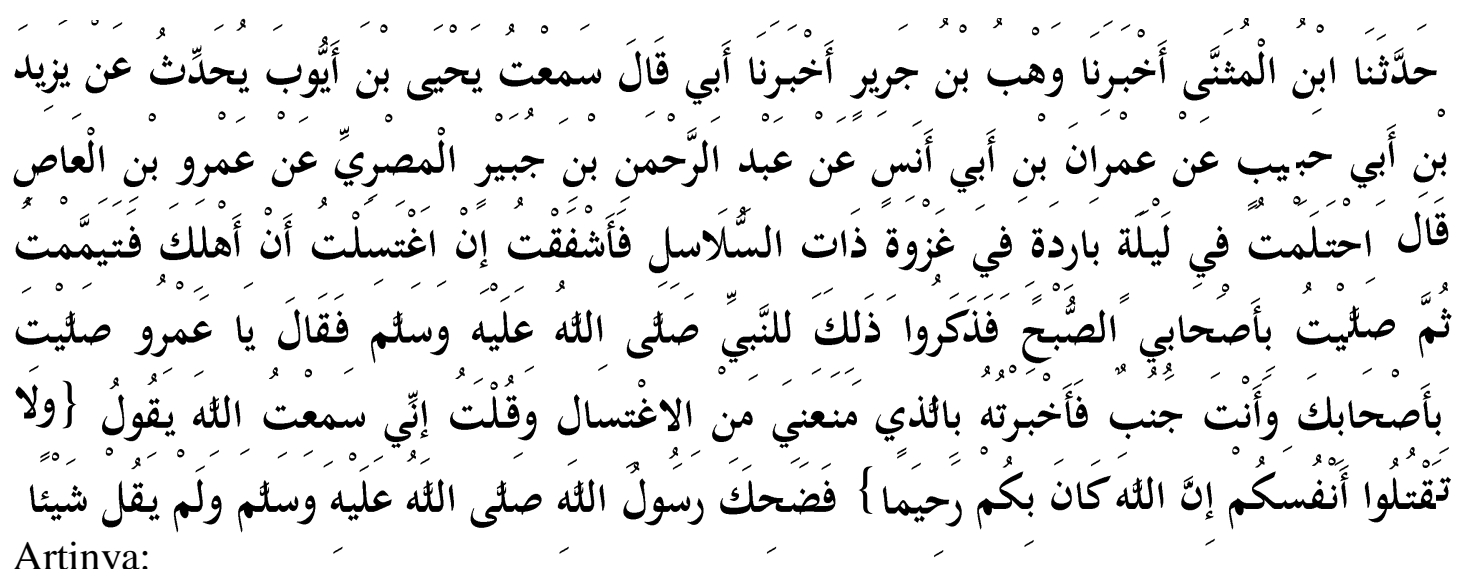

"Telah menceritakan kepada kami Ibnu Al-Mushanna telah mengabarkan kepada kami Wahb bin Jarîr telah mengabarkan kepada kami Ayahku dia berkata; Saya telah mendengar Yahya bin Ayyub menceritakan hadits dari Yazid bin Abi Habib dari Imran bin Abi Anas dari Abdurrahman bin Jubair AlMisri dari Amru bin Al-'As \} dia berkata; Saya pernah bermimpi basah pada suatu malam yang sangat dingin sekali ketika perang Zâti al-Sulâsil, sehingga saya takut akan binasa jika saya mandi. Lalu saya pun bertayammum kemudian shalat Shubuh dengan para sahabatku. Lalu hal itu mereka laporkan kepada Nabi saw., maka beliau bersabda: "Wahai Amru, engkau shalat bersama para 
sahabatmu dalam keadaan junub?" Maka saya katakan kapada beliau tentang apa yang menghalangiku untuk mandi dan saya katakan; Sesungguhnya saya pernah mendengar Allah berfirman: 'Dan janganlah kalian membunuh diri-diri kalian, sesungguhnya Allah Maha Penyayang kepada kalian.(QS. Al-Nisâ'; 29), Maka Rasulullah saw. tertawa dan tidak mengatakan apa-apa”.

Hadis di atas menjelaskan bahwasanya Rasulullah saw. pernah membenarkan tindakan 'Amru bin al-'Ash ketika perang Zâti al-Salâsil. Saat itu 'Amru bin al-'Ash sedang dalam keadaan junub dan khawatir untuk mandi dengan air yang sangat dingin karena takut terjadi sesuatu terhadap dirinya. Maka beliau pun bertayammum kemudian melaksanakan shalat subuh. Beliau beralasan dengan dalil firman Allah

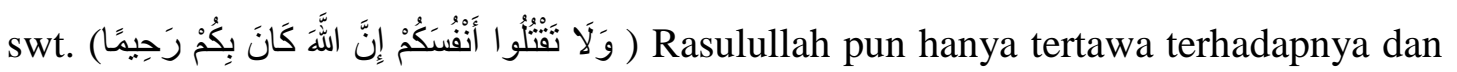
tidak mengatakan sesuatu apa pun (al-Qurthubî, 1964: 157).

Riwayat di atas membuktikan bahwasanya menjauhi atau menghindari perbuatan yang dapat membahayakan diri sendiri merupakan hal yang wajib dilakukan. Sebaliknya harus menjauhi dan menghindari sesuatu perbuatan yang dapat membawa diri kepada kehancuran dan kebinasaan.

Islam menghendaki kepada setiap muslim hendaknya selalu optimis dalam menghadapi setiap musibah. Oleh karena itu Islam tidak membenarkan dalam situasi apa pun untuk mengakhiri hidup dengan cara yang dipaksakan, hal ini sesuai dengan pokok-pokok ajaran Islam yang melindungi kepentingan manusia melalui lima prinsip (dharûriyât al-khamsah) yakni, Hifzh al-dîn atau menjamin kebebasan beragama, Hifzh al-nafs atau memelihara kelangsungan hidup, Hifzh al-'aql atau menjamin kreatifitas berfikir, Hifzh al-nas ll atau menjamin keturunan dan kehormatan, Hifzh al-mâl atau kebebasan memiliki harta (Syahrul Anwar, 2010: 76).

Ulama fiqh bersepakat bahwa bunuh diri hukumnya haram, dan dianggap sebagai dosa terbesar setelah syirik (Alî bin Nâyif al-Syuhûd, 2011: 43). Sebagaimana firman Allah swt. dalam QS al-Nisâ'/4; 29-30:

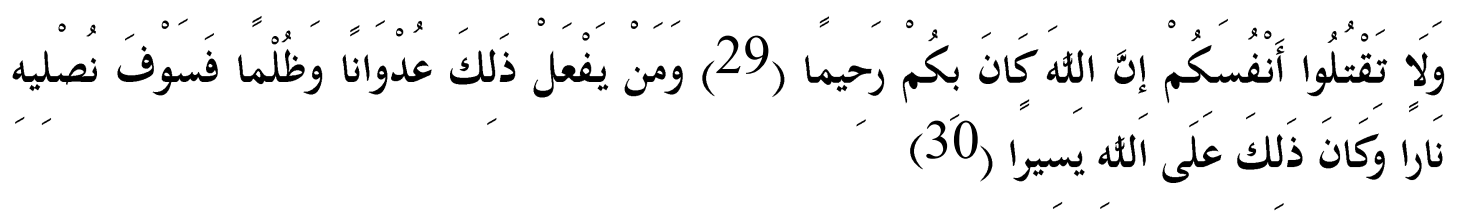


Terjemahnya:

"Dan janganlah kamu membunuh dirimu; Sesungguhnya Allah adalah Maha Penyayang kepadamu. dan Barangsiapa berbuat demikian dengan melanggar hak dan aniaya, Maka Kami kelak akan memasukkannya ke dalam neraka. yang demikian itu adalah mudah bagi Allah" (Kemenag RI, 2011: 83).

Dan firman Allah swt. dalam QS al-An'âm/6: 151:

Terjemahnya:

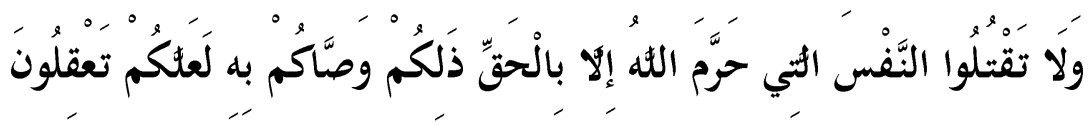

"Dan janganlah kamu membunuh jiwa yang diharamkan Allah (membunuhnya) melainkan dengan sesuatu (sebab) yang benar, demikian itu yang diperintahkan kepadamu supaya kamu memahami(nya)” (Kemenag RI, 2011: 148).

Dalam beberapa hadis Rasulullah saw. yang lain juga dijelaskan mengenai

kekekalan para pelaku bunuh diri dalam neraka dan balasan bagi mereka. Di antaranya (al-Bukhâri, t.th.: 139):

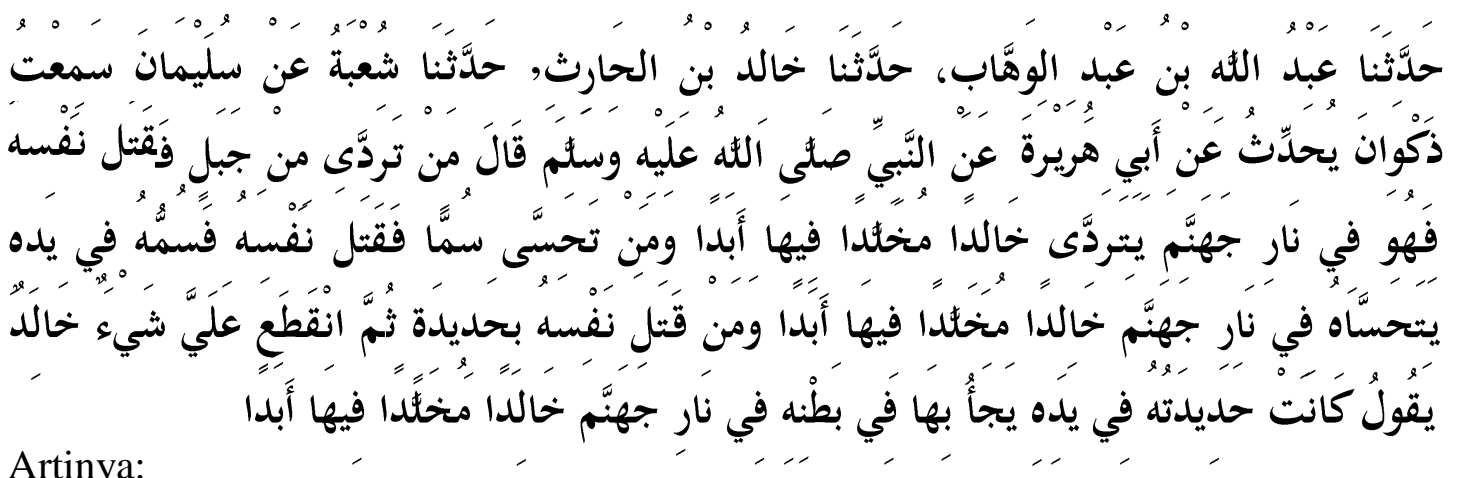

"Telah menceritakan kepada kami Abdul Wahhab; telah menceritakan kepada kami Khalid bin al-Hâris; telah menceritakan kepada kami Syu'bah dari Sulaiman; Aku mendengar Zakwan menceritakan dari Abu Hurairah dari Nabi saw. beliau bersabda: "Siapa yang menjatuhkan diri dari gunung, lalu meninggal dunia, ia akan jatuh ke neraka jahannam, ia kekal serta abadi di dalamnya selama-lamanya. Barangsiapa yang menegak racun, lalu meninggal dunia, racunnya ada di tangannya, ia akan menegaknya di neraka jahannam, ia kekal serta abadi di dalamnya selama-lamanya. Dan barang siapa yang bunuh diri dengan besi, besi itu akan ada di tangannya, dengannya ia akan menghujamkan ke perutnya di neraka jahannam, ia kekal dan abadi di dalamnya selama-lamanya".

Syaikh Muhammad Mutawallî al-Sya'râwi mengatakan dalam bukunya al-

Hayât wa al-Mawt sebagaimana dikutip oleh Ahmad al-Mursi Husain Jauhar, orang yang membunuh dirinya sendiri divonis akan kekal dan dikekalkan di neraka. 
Mengapa? Karena manusia tidak dapat menciptakan sendiri, maka mengapa dia membunuh dirinya? Allah-lah Yang menciptakannya, dan ruh serta hidup manusia adalah milik Allah swt. jika manusia bunuh diri, berarti dia menghancurkan atau merusak sesuatu yang bukan miliknya. Orang yang membunuh satu jiwa dengan tidak sengaja diharuskan membayar diyât (denda). Adapun orang yang membunuh orang lain dengan sengaja, maka dia berhak mendapatkan balasan (siksa) (Ahmad al-Mursi Husain Jauhar, 2009: 29-29).

Berdasarkan hal tersebut, maka tindakan bunuh diri termasuk perkara keji dan perbuatan menghancurkan. Orang yang melakukannya telah menyalahi fitrah yang diciptakan Allah swt. kepadanya. Balasan berupa neraka bagi pelaku bunuh diri dan kekekalan mereka di dalamnya serta keharaman mereka terhadap surga merupakan indikasi bahwasanya pelaku bunuh diri dianggap kafir. Karena, kekekalan di dalam neraka dan keharaman terhadap surga merupakan balasan bagi orang-orang kafir (Alî bin Nâyif al-Syuhûd, 2011: 57).

Ulama fiqh menetapkan bahwasanya dosa membunuh diri sendiri lebih besar dari pada dosa membunuh orang lain, dan pelakunya dianggap fâsiq karena dia menginginkan hal tersebut untuk dirinya sendiri. Bahkan sebagian ulama berpendapat bahwa pelaku bunuh diri tidak boleh dimandikan dan dishalatkan (Alî bin Nâyif alSyuhûd, 2011: 43).

Pendapat berbeda dikemukakan oleh M. Quraish Shihab, menurut beliau, jika yang bersangkutan hingga akhir hayatnya tetap mengucapkan dua kalimat syahadat, maka dia tetap diperlakukan sebagai Muslim, dishalati, dan dimakamkan dalam pekuburan Islam. Dia bukan kafir dalam istilah hukum, dan bukan pula musyrik. Dia dinamai muslim yang durhaka. Mendoakannya pun tidak terlarang, karena yang terlarang didoakan setelah kematiannya hanyalah orang musyrik atau orang yang mempersekutukan Allah swt. sedangkan membunuh dirinya sendiri, tidak mengakibatkan kemusyrikan (M. Quraish Shihab, 2009: 782).

Mendambakan kematian merupakan salah satu bentuk keputus asaan, sedang tidaklah wajar seorang muslim berputus asa dari rahmat Allah, betapa pun besar 
penderitaannya. Kalaupun terpaksa, akibat penderitaan yang tidak terpikul lagi, maka hendaklah dia berdoa: "Ya Allah hidupkan aku jika kehidupan ini baik untukku, dan matikan aku, jika kematian baik bagiku." Karena itu bunuh diri sama sekali tidak dibenarkan dengan alasan apa pun. Hidup adalah anugerah Allah swt. Dia yang menganugerahkan maka Dia pula yang berhak mencabutnya. Jangankan membunuh orang lain, membunuh diri sendiri pun tidak dibenarkan (M. Quraish Shihab, 2005: 41).

Bunuh diri adalah pembunuhan seseorang terhadap dirinya sendiri dengan sengaja, dengan sebab apa pun dan itu adalah diharamkan, dan termasuk dalam kategori dosa besar (Abu Anas Ali bin Husain Abu Lauz, 2004: 117). Hal itu berada dalam keumuman firman Allah swt. dalam QS al-Nisâ'/4: 93:

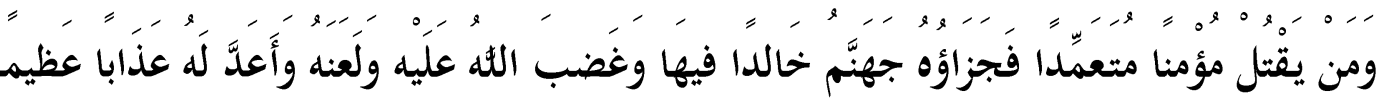

Terjemahnya:

"Barangsiapa yang membunuh seorang mukmin dengan sengaja maka balasannya ialah jahannam, Dia kekal di dalamnya dan Allah murka kepadanya, dan mengutuknya serta menyediakan azab yang besar baginya" (Kemenag RI, 2011: 93).

Adapun bentuk bunuh diri yang masih menjadi perdebatan dikalangan ulama mengenai hukumnya adalah bunuh diri guna melakukan perlawanan terhadap musuh Islam sebagai bentuk jihad membela agama Allah swt. tipe bunuh diri seperti ini oleh Emile Durkheim dikategorikan sebagai altruistic suicide.

Dalam literatur Islam keinginan kuat untuk mati dalam jihad diistilahkan dengan istisyhâd yang berarti ( طلب الثهادة ) atau mencari kesyahidan. Sedangkan orang yang meninggal dalam mencari kesyahidan di jalan Allah disebut dengan Syâhid (Ibnu Manzhur, 1414 H: 242).

Kesamaan antara istisyhâd dan intihâr adalah adanya tujuan yang sama yaitu keinginan untuk mati. Tetapi perbedaannya terletak pada motivasi melakukan hal tersebut, istisyhâd adalah melakukan perlawanan kepada musuh dan didorong oleh rasa pengorbanan. Sedangkan intihâr adalah karena keputus asaan dan untuk mengakhiri persoalan hidup. 
Yusuf Qardhawi menyebutkan perbedaan praktek istisyhâd dan intihâr antara lain:

1. Orang yang bunuh diri adalah akibat dari kegagalan dirinya dalam transaksi, cinta, ujian atau hal-hal lainnya. Ia tidak berdaya dalam menghadapi kenyataan, lalu memutuskan untuk lari dari kehidupan dengan menjemput kematian. Sementara istisyhâd sama sekali tidak memandang kepentingan dirinya sendiri. Orang yang melakukan praktek syahid rela mengorbankan dirinya untuk kepentingan yang besar. Untuk mewujudkan tujuan tersebut, ia memandang remeh segala pengorbanan. Ia menjual dirinya kepada Allah swt. untuk membeli surga.

2. Orang yang bunuh diri mati karena menghindar dan mundur karena takut, sedangkan orang yang melakukan praktik syahid meninggal karena berani maju dan menyerang.

3. Orang yang bunuh diri tidak memiliki tujuan selain lari dari pertarungan, sebaliknya orang yang melakukan praktek syahid memiliki tujuan yang jelas, yaitu meraih ridha Allah swt. (Yusuf Qardhawi, 2010: 902). Sebagaimana firman Allah swt. dalam QS al-Baqarah/2: 207:

\section{Terjemahnya:}

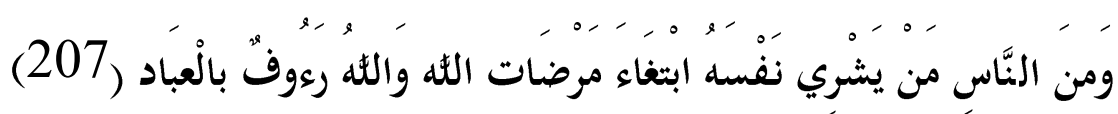

"Dan di antara manusia ada orang yang mengorbankan dirinya karena mencari keridhaan Allah; dan Allah Maha Penyantun kepada hamba-hamba-Nya" (Kemenag RI, 2022: 32).

Dari perbedaan itu, Yusuf Qardhawi menyebutkan tentang keabsahan praktek bom bunuh diri (istisyhâdiyyah) yang dilakukan di Palestina. Bahwa praktek istisyhâdiyyah yang dilakukan kelompok-kelompok perlawanan Palestina untuk melawan penduduk Zionis, tidak termasuk dalam hal yang dilarang dengan alasan apa pun, walaupun yang menjadi korban adalah penduduk sipil. Kebolehan dari praktik istisyhâdiyyah ini harus memperhatikan dua hal:

1. Memperbolehkan praktek istisyhâdiyyah bagi saudara-saudara di Palestina karena kondisi khusus mereka dalam membela diri, keluarga, anak-anak dan kemuliaan 
mereka. Itulah yang memaksa mereka menggunakan cara tersebut, karena tidak menemukan ganti perlawanannya.

2. Jika sudah mendapatkan ganti perlawanan mereka yaitu dengan persenjataan, maka tidak lagi dibutuhkan praktek istisyhâdiyyah (Yusuf Qardhawi, 2010: 904).

Istinbât hukum yang digunakan Yusuf Qardhawi dari kebolehannya melakukan praktek istisyhâdiyyah bahwa praktek tersebut harus melihat keadaan dan kondisi. Dari kondisi tersebut melahirkan suatu hukum yang mana hukum ada dua jenis, yaitu hukum dalam kondisi normal dan hukum dalam kondisi darurat. Dalam kondisi darurat, dibolehkan bagi seorang Muslim apa-apa yang tidak dibolehkan dalam kondisi normal. Sehingga ketika dalam kondisi darurat maka kaidah us\}âul yang menyatakan الضرورة تبيح المحظورة yang berarti istisyhâdiyyah sebagai bentuk dari keterpaksaan untuk melakukan perlawanan (Yusuf Qardhawi, 2010: 988-990).

\section{B. Dampak Perbuatan Bunuh Diri}

Apabila manusia mengenal logika Islam bahwa kematian bukanlah ujung perjalanan melainkan awal perjalanan tanpa ujung dan batas, maka mereka akan mengetahui bahwasanya bunuh diri sama sekali tidak akan membantu manusia menyelesaikan persoalan yang dihadapinya. Di samping itu, tiada satu pun, termasuk berbagai kesulitan hidup, yang berharga di dunia ini yang melebihi harga jiwa yang direnggutnya dengan bunuh diri.

Dengan bunuh diri, seseorang akan merasakan penderitaan tiga kali, yaitu penderitaan di dunia yang mendorongnya berbuat seperti itu, penderitaan menjelang kematiannya, dan penderitaan yang kekal di akhirat nanti.

Penderitaan di dunia seperti mengalami depresi yang mendalam, putus asa, tidak memiliki motivasi dan semangat hidup, dan sebagainya membuatnya tidak bisa menikmati indahnya kehidupan.

Selain merasakan penderitaan ketika hidup, pelaku bunuh diri juga akan mengalami penderitaan yang tidak kalah pedihnya sebelum mati atau ketika ruh berpisah dengan jasadnya (sakarât al-maut). Dalam keadaan mati mendadak, seperti 
bunuh diri, sakarât al-maut itu hanya terjadi beberapa saat dengan singkat, yang mengalaminya akan merasa sangat sakit karena kematian yang dihadapinya ketika itu diibaratkan oleh Nabi saw. seperti "duri yang berada dalam kapas, dan kemudian dicabut dengan keras.” Banyak ulama tafsir yang menunjuk ayat وَالنَّازِ عَاتِ غَرًْْا (Demi malaikat-malaikat yang mencabut nyawa dengan keras) sebagai isyarat kematian secara mendadak (M. Quraish Shihab, 2013: 102).

Penderitaan yang paling berat bagi pelaku bunuh diri adalah kekekalan mereka di neraka nanti. Allah dan Rasul-Nya mengancam para pelaku bunuh diri yang membunuh dirinya, mempercepat hidupnya, dan menghilangkan nyawa dengan berbagai siksa di akhirat, pada hari semua makhluk berdiri menghadap Tuhan semesta alam. Dia menjadi orang yang dilaknat dan dijauhkan dari rahmat Allah, dan surga adalah haram baginya, dia dikekalkan di neraka, dan siksaannya adalah dengan menggunakan sesuatu yang digunakannya untuk membunuh dirinya dan menghilangkan nyawanya (Ahmad al-Mursi Husain Jauhar, 2009: 29).

\section{Upaya Pencegahan Tindakan Bunuh Diri}

Bunuh diri merupakan masalah yang kompleks karena tidak diakibatkan oleh penyebab atau alasan tunggal. Tindakan bunuh diri merupakan interaksi yang kompleks dari faktor psikologik, sosial, budaya dan lingkungan. Sulit untuk menjelaskan mengenai penyebab mengapa orang memutuskan untuk melakukan bunuh diri, sedangkan yang lain dalam kondisi yang sama bahkan lebih buruk tetapi tidak melakukannya. Meskipun demikian, tindakan bunuh diri atau percobaan bunuh diri pada umumnya dapat dicegah.

Bunuh diri terjadi karena sempitnya pemikiran seseorang dalam menghadapi suatu masalah. Dan ini terjadi karena seseorang memisahkan diri dari Tuhannya. Apabila seseorang mengingat bahwasanya ada Tuhan yang selalu bersamanya maka niscaya akan hilang darinya kesusahan. Maka masalah apa pun yang menghampiri, 
katakanlah ( إِنَّ مَعِيَ رَبِّي سَتَهْدِينِ ) "Sesungguhnya Tuhanku bersamaku akan memberiku petunjuk" (asy-Sya'râwî, 1997: 2148).

Menurut pakar psikologi, salah satu hal yang cukup penting dalam mencegah tindakan bunuh diri adalah, memelihara kesehatan mental. Abdul Mujib dan Jusuf Mudzakkir mengutip dalam bukunya mengenai dua pola Musthafa fahmi dalam mendefinisikan kesehatan mental sebagaimana dikutip oleh Muhammad Mahmud Mahmud dalam buku karangannya 'Ilm al-nafs al-ma'âsir fî D\}aw'i al-islâm: Pertama, pola negatif (salabiy), bahwa kesehatan mental adalah terhindarnya seseorang dari segala neurosis (al-amrâd al-'ashabiyah) dan psikosis (al-amrâd\} alzihaniyah). Kedua, pola positif (ijabiy), bahwa kesehatan mental adalah kemampuan individu dalam penyesuaian terhadap diri sendiri dan terhadap lingkungan sosialnya (Abdul Mujib dan Jusuf Mudzakkir, 2002: 133).

Menurut Abdul Mujib dan Jusuf Mudzakkir ada tiga metode perolehan dan pemeliharaan kesehatan mental yang meliputi segala aspek kehidupan manusia, yaitu; Pertama, metode iman yang berkaitan dengan prinsip-prinsip kepercayaan dan keyakinan kepada Tuhan dan kepada hal-hal yang gaib; kedua, metode islam yang berkaitan dengan prinsip-prinsip ibadah dan muamalah; ketiga, metode ihsan yang berkaitan dengan prinsip-prinsip moral atau etika.

\section{Metode Imaniah}

Iman memotivasi individu untuk selalu hidup dalam kondisi sehat, baik jasmani maupun ruhani. Dengan iman, seseorang memiliki tempat bergantung, tempat mengadu, dan tempat memohon apabila ia ditimpa problema atau kesulitan hidup, baik yang berkaitan dengan perilaku fisik maupun psikis. Ketika seseorang telah mengerahkan daya upayanya secara maksimal untuk mencapai satu tujuan, namun tetap mengalami kegagalan, tidak berarti kemudian ia putus asa atau bunuh diri.keimanan akan mengarahkan seseorang untuk mengkoreksi diri apakah prosedur yang dilakukan untuk mencapai tujuan sudah sesuai atau belum dengan hukum-hukum Tuhan yang pasti, jika sesuai dengan hukum-hukum-Nya, tetapi masih mengalami kegagalan, maka yang perlu diperhatikan adalah hikmah dibalik 
kegagalan itu. Apakah Allah swt. menguji kualitas keimanannya melalui kegagalan. Ataukah, dia mengasihi hamba-Nya yang słâlih agar tidak sombong atau angkuh ketika memperoleh kesuksesan.

\section{Metode Islamiah}

Islam secara terminologi sebagaimana yang tertulis dalam hadis di atas adalah pengakuan dan penyerahan diri secara mutlak kepada Zat Yang maha Besar, yakni Allah swt. dengan segala peraturan-Nya. Realisasi metode islam dapat membentuk kepribadian muslim yang mendorong seseorang untuk hidup bersih, suci dan dapat menyesuaikan diri dalam setiap kondisi. Kondisi seperti itu merupakan syarat mutlak bagi terciptanya kesehatan mental.

\section{Metode Ihsaniah}

Ihsan secara bahasa berarti baik. Orang yang baik adalah orang yang mengetahui akan hal-hal yang baik, mengaplikasikan dengan prosedur yang baik, dan dilakukan dengan niatan yang baik pula. Orang yang berbuat baik berarti menempuh jalan yang tidak mengandung resiko, sehingga hidupnya terhindar dari permusuhan, pertikaian, dan iri hati. Ihsan secara istilah sebagaimana yang tergambar dalam hadis di atas adalah usaha untuk memperbaiki kualitas perilaku. Kualitas ini dicapai melalui upaya mendekatkan diri kepada Allah swt., sehingga dalam gerak-gerik tingkah lakunya seakan-akan melihat Allah. Apabila ia tidak mampu melihat-Nya maka sesungguhnya Allah telah melihatnya (Abdul Mujib dan Jusuf Mudzakkir, 2002: 150-161).

\section{KESIMPULAN}

Berdasarkan dari keseluruhan uraian yang telah dipaparkan pada bab-bab sebelumnya, maka dapatlah ditarik beberapa kesimpulan yaitu; Pertama, bunuh diri adalah suatu tindakan tercela yang dengan sengaja mematikan diri sendiri dengan berbagai cara. Perbuatan ini adalah sebuah tindakan mendahului takdir kematian yang telah ditentukan oleh Allah swt.. Tindakan ini sangat diharamkan dan termasuk dalam 
golongan dosa besar dan pelakunya diancam dengan kekekalan di dalam neraka. Kedua, dampak dari perbuatan bunuh diri bagi seseorang ada tiga; pertama, penderitaan di dunia semasa hidup, seperti mengalami depresi yang mendalam, putus asa, tidak mempunyai semangat dan motivasi hidup. Kedua, penderitaan ketika sakarât al-mawt. Pelaku bunuh diri akan merasakan sakit yang sangat ketika ruh berpisah dengan jasad karena kematiannya secara mendadak. Rasa sakit itu diibaratkan seperti "duri yang berada dalam kapas, dan kemudian dicabut dengan keras". Ketiga, penderitaan di akhirat kelak. Allah dan Rasul-Nya mengancam para pelaku bunuh diri dengan dikekalkan di neraka, dan siksaannya adalah dengan menggunakan sesuatu yang digunakannya untuk membunuh dirinya. Ketiga, tindakan bunuh diri dapat dicegah dengan cara memelihara kesehatan mental menggunakan tiga metode.

\section{DAFTAR PUSTAKA}

Abu Lauz, Abu Anas Ali bin Husain. (2004). Kaifa Nu'aliju Wâqi'ana al-Alîm Min Aqwâl wa Fatawa, terj. Dahlan Haranawisastera, Salah Kaprah dalam Memperjuangkan Islam. Jakarta: Pustaka al-Sofwa.

Anwar, Syahrul. (2010). Ilmu Fiqh dan Ushul Fiqh. Bogor: Ghalia Indonesia.

Al-Bagawî, Abu Muhammad al-Husain bin Mas'ud. (1997). Ma'alim al-Tanzîl fi. Tafsîr al-Qur'ân. t.t: dâr thayyibah lî al-Nasyr wa al-Tauzî'.

Al-Bukhârî al-Ja'fî, Muhammad bin Ismaîl abu Abdillah. (1422 H). Shahîh alBukhârî. t.t: Dâr Thawqu al-Najâh.

Departemen Agama RI. (2010). Al-Qur'ân dan Tafsirnya. Jakarta: Lentera Abadi.

Departemen Pendidikan Nasional. (2008). Kamus Besar Bahasa Indonesia Pusat Bahasa. Jakarta: PT. Gramedia Pustaka Utama.

Echols, John M. dan Hassan Shadily. (2003). Kamus Inggris - indonesia. Jakarta; PT Gramedia Pustaka Utama. 
Ghazali, Syeikh Muhammad. (2005). Nahw Tafsîr Mawd\}彳̂u'iy lî Suwar al-Qur'ân, Terj. M. Qodirun Nur dan Ahmad Musyafiq, Tafsir Tematik dalam al-Qur'an. Jakarta: Gaya media.

Hamka. (t.th.). Tafsir al-Azhar. t.t: Pustaka Nasional.

Husain Jauhar, Ahmad al-Mursi. (2009). Maqâsid al-Syarî'ah fî al-Islâm. terj. Khikmawati, Maqâsid Syarî'ah. Jakarta: Sinar Grafika.

Ibnu Manzûr, Jamaluddîn. (1414H). Lisân al- 'Arab. Beirut: Dâr Shâdir.

Ibnu Zakariya, Abu al-Husain Ahmad ibn Fâris. (1979). Mu'jam Maqayis al-Lugat. t.t: Dâr al-Fikr.

Al-Jazâirî, Jâbir bin Musa bin Abdil Qâdir bin Jâbir Abu Bakr. (2003). Aysaru alTafâsîr likalâmi al- 'Alîy al-Kabîr. Madinah: Maktabah al-'Ulûm wa al-Hukm.

Kementerian Agama RI. (2011). Al-Qur'an dan Terjemahnya Dilengkapi dengan Kajian Usul Fiqih dan Intisari Ayat. Bandung: Sygma Publishing.

Al-Marâgi, Ahmad Musthafa. (1946). Tafsîr al-Marâgi. t.t: Syirkah Maktabah.

Mudzakkir, Abdul Mujib dan Jusuf. (2002). Nuansa-nuansa Psikologi Islam. Jakarta: PT Raja Grafindo Persada.

Muhaiyaddeen, M.R. Bawa. (2004). To Die Before Death: The Sufi Way of Life terj. M. Sadat Ismail, Mati Sebelum Mati: Jalan Hidup Sang Sufi. Yogyakarta: Pustaka Pelajar.

Munawwir, Ahmad Warson. (1997). Kamus Al-Munawwir Arab-Indonesia Terlengkap. Surabaya: Pustaka Progressif.

Mushthafa, Ibrâhim dkk. (t.th.). Al-Mu’jam al-Wasîth. t.t.: Dâr al-Da'wah.

An-Naisabûrî, Muslim bin al-Hajjaj abû al-Hasan al-Qusyayrî. (t.th.). Shahih Muslim. Beirut: Dâr Ihyâ' al-Turast al-‘Arabîy. , Abû Bakr Muhammad bin Ibrâhim bin al-Munzhir. (2002). Kitâb Tafsîr alQur'ân. Madinah: Dâr al-Ma'âshir. 
Al-Qardhâwi, Yusuf. (2010). Fiqh al-Jihâd, terj. Irfan Maulana Hakim, Fiqih Jihad: Sebuah Karya Monumental dan Terlengkap Tentang Jihad Menurut alQur'an dan Sunnah. Bandung: Mizan.

Al-Qurtubî, Abu Abdillah Muhammad bin ahmad bin Abi Bakr bin farh al-Anslârî alKhazrijî Syamsuddin. (1964). Al-Jâmi' lî ahkâm al-Qur'ân : Tafsîr alQurtubî. al-Qâhirah: Dâr al-Kutub al-Mishriyyah.

Shihab, M. Quraish. (2005). Menjemput maut, Bekal Perjalanan Menuju Allah Swt. Tangerang: Lentera Hati. ,(2009). M. Quraish Shihab Menjawab 1001 Soal Keislaman yang Patut anda Ketahui. Tangerang: Lentera Hati. 